\title{
Distillation of butyrate of lime
}

\section{M.G. Chancel}

To cite this article: M.G. Chancel (1845) Distillation of butyrate of lime, Philosophical Magazine Series 3, 26:172, 267-268, DOI: 10.1080/14786444508645120

To link to this article: http://dx.doi.org/10.1080/14786444508645120

曲 Published online: 30 Apr 2009.

Submit your article to this journal 준

Џ Article views: 2

Q View related articles $₫$ 
April 6, 1660; third, paraselenæ, December 17, 1660; and fourth, parhelia, February 20,1661. That noticed by Hevelius on the 30th of March, 1660, was very similar to the one seen at High Field House on the 21 st of October, 1844 ; only this was parhelia, and that de. scribed by the Polish astronomer paraselenæ.

Since the appearance of the parhelia on the 21st of October, 1844, we have had a very considerable fall of rain.

High Field House, Lenton, Nottinghamshire, $\quad$ E. J. Lowz. November 8,1844 .

Distillation OF BUTYRATE OF LIME. BY M. G. CHANCEL.

When a small quantity of this salt, anhydrous and pure, is cautiously heated, it is quickly decomposed into carbonic acid, which remains combined with the lime, and a volatile oil which distils; this oil is butyrone, nearly pure and only slightly coloured; the residue consists entirely of carbonate of lime, which is perfectly white and pure. When care is taken not to exceed the temperature requisite for the formation of butyrone, with a quantity not exceeding about 100 grains, not the slightest trace of charcoal is deposited.

Most commonly no gas is evolved, unless the heat be too great; in this case the quantity of gaseous products amounts to 3 or 4 per cent. of the butyrate acted upon. The greater portion is formed of bicarburetted hydrogen absorbable by sulphuric acid.

It is worthy of remark, that, provided anhydrous butyrate be em. ployed, no water is in any case disengaged, and yet it is well known that the distillation of organic matter is almost always accompanied with the formation of some water at the expense of the elements of the organic body.

When, however, considerable quantities of the butyrate of lime are submitted to distillation, the operation is far from being as simple; in this case the author could not avoid the deposition of some charcoal, and the liquid products obtained were always considerably coloured; this may be attributed to the ulterior decomposition of a portion of the butyrone formed, on account of the unequal distribution of the heat throughout the mass. In this case there is thus formed a mixture of several liquid substances, in which butyrone is the prevailing one.

In several distillations 100 parts of anhydrous butyrate of lime yielded from 42 to 43 parts of rough butyrone.

\section{Preparation of pure Butyrone.}

When the above-described impure liquid is submitted to distillation, the boiling-point, which is at first under $212^{\circ}$, soon rises nearly to $284^{\circ}$; the fluid which rises between $284^{\circ}$ and $293^{\circ}$ is to be kept separate, and is entirely butyrone; the products which are collected previously and subsequently are mixtures of butyrone, and two peculiar substances, one of which distils below $212^{\circ}$ and the other at above $320^{\circ}$; the butyrone distilled between $284^{\circ}$ and $293^{\circ}$, once redistilled, has a constant boiling-point, and may be regarded as pure butyrone. 
The properties of butyrone are, that it is a colourless limpid liquid, possessing a strong peculiar odour and a burning taste; its density is 0.83 , and it boils at about $290^{\circ}$; when submitted to cold produced by solid carbonic acid and ather, it becomes a crystalline mass. It floats on the surface of water, in which it appears to be nearly insoluble, although it imparts its odour to it; it mixes with alcohol in all proportions; it is readily inflammable and burns with a bright flame. The action of chromic acid on butyrone is extremely vivid, it burns as soon as they come into contact; it does not acquire colour by exposure to the air, although it eventually absorbs a considerable quantity of oxygen.

Several analyses of this substance gave similar results, which indicated as its formula $\mathrm{C}^{7} \mathrm{H}^{7} \mathrm{O}$; the density of the vapour confirms this formula. Experiment gave the number $4 \cdot 0$, very near the theoretic number 3.96. The formula $\mathrm{C}^{7} \mathrm{H}^{7} \mathrm{O}$ therefore represents two volumes of the vapour of butyrone.

This composition sufficiently explains the formation of this substance; butyrate of lime, submitted to distillation, is decomposed into carbonic acid, which remains combined with the base; and in butyrone, which distils, this is shown by the following equation:-

$$
\underbrace{\mathrm{CaO}, \mathrm{C}^{9} \mathrm{H}^{7} \mathrm{O}^{8}}_{\text {Butyrate of lime. }}=\underbrace{\mathrm{CaO}, \mathrm{CO}^{2}}_{\text {Carb. of lime. Butyrone. }}+\underbrace{\mathrm{C}^{7} \mathrm{H}^{7} \mathrm{O}}
$$

Thus the dry distillation of butyrate of lime is not less perfect than that of the acetate of the same base; the decomposition takes place readily, and the quantity of butyrone obtained under proper circumstances agrees with the indications of theory.-Ann. de Ch. et de Phys., October 1844.

POTASH AND OXIDE OF CHROMIUM. BY M. FREMT.

Hydrated oxide of chromium dissolves in the alkalies and forms a green solution, which has the same green colour as the salts of chromium. The author could not succeed in obtaining definite compounds of oxide of chromium and an alkali, owing to the extreme instability of these compounds ; the history of the compounds of oxide of chromium with bases may be reduced to the following facts:-

Oxide of chromium, like that of zinc, dissolves only in the alkalies when it is hydrated; when anhydrous it is insoluble in alkaline solutions; when oxide of chromium combined with an alkali is dehydrated, it immediately quits the base and is precipitated; so that when oxide of chromium is dissolved in potash, the solution remains bright while it is not heated, but if boiled the metallic oxide is dehydrated by the action of the potash and is precipitated; if also a solution of oxide of chromium in potash be evaporated in vacwo, it is decomposed, and the effect is more rapid when the solution is strongly alkaline; these effects are produced upon several oxides soluble in the alkalies. When potash and oxide of chromium are calcined together in a silver crucible, the oxide absorbs oxygen and a chromate is formed. 